\title{
FAKTOR-FAKTOR YANG MEMPENGARUHI IMPOR GANDUM INDONESIA
}

\author{
Factors that Affect the Indonesian Wheat Imports
}

\author{
Yogi Pradeksa $^{1)}$, Dwidjono Hadi Darwanto ${ }^{2)}$, Masyhuri ${ }^{2)}$ \\ 1) Jurusan Sosial Ekonomi Pertanian Fakultas Pertanian Universitas Gadjah Mada \\ ${ }^{2)}$ Fakultas Pertanian Universitas Gadjah Mada
}

\begin{abstract}
The purpose of this research are to determine the factors that influence the Indonesian wheat imports and the trend of Indonesian wheat imports. The method used in this research was descriptive analysis method using time series data from the years 1992 to 2011. The variables used are national income (GNP), population, international wheat prices, domestic rice prices, exchange rates, and the use of wheat flour by industry. The trend of import volume of wheat showed that there will be additional of import wheat volume around of 11.793 ton per year. Determinant factors which significantly affecting import volume of wheat are national income (GNP), population, international wheat prices and exchange rates, while the domestic rice prices and the use of wheat flour by industry had no significant effect on the volume of imports.
\end{abstract}

Keywords: wheat, import, Indonesia

\section{INTISARI}

Tujuan dari penelitian ini adalah untuk mengetahui faktor-faktor yang mempengaruhi impor gandum Indonesia dan untuk mengetahui trend impor gandum Indonesia. Metode yang digunakan dalam penelitian ini adalah metode analisis deskriptif dengan menggunakan data time series dari tahun 1992-2011. Variabel-variabel yang digunakan adalah pendapatan nasional (GNP), jumlah penduduk, harga gandum internasional, harga beras domestik, kurs, dan penggunaan tepung terigu oleh industri. Analisis trend impor gandum menunjukkan hasil bahwa setiap tahunnya mengalami peningkatan volume impor sebesar 11.793 ton. GNP, jumlah penduduk, harga gandum internasional dan kurs berpengaruh secara signifikan terhadap volume impor, sedangkan harga beras domestik dan penggunaan tepung terigu oleh industri tidak berpengaruh signifikan terhadap volume impor.

Kata Kunci: gandum, impor, Indonesia

\section{PENDAHULUAN}

Gandum sesungguhnya bukan makanan pokok masyarakat Indonesia, namun selama beberapa tahun terakhir perannya semakin penting. Peralihan pola konsumsi kelompok berpendapatan bawah dan menengah yang begitu cepat ke makanan yang berasal dari gandum terutama mi instan dan roti, telah mendorong peningkatan impor gandum atau terigu, serta berkurangnya permintaan pangan yang berasal dari sumberdaya dalam negeri seperti ketela dan umbi-umbian lainnya.

Gandum merupakan komoditas pangan yang terbanyak diproduksi di dunia dibanding jagung dan padi, bahkan jumlah produksinya dari tahun ke tahun semakin meningkat. Dengan tingkat pertumbuhan produksi rata-rata 2-3\% pertahun, gandum menjadi tanaman utama di dunia. Permintaan akan gandum tidak terlepas dari banyaknya derivasi produk yang bisa dihasilkan dari gandum. Jika diolah menjadi tepung, turunan gandum ini dapat digunakan untuk membuat berbagai macam makanan. Dari segi modernitas pangan, gandum lebih unggul dari tanaman serealia lain seperti jagung dan padi. Gandum merupakan salah satu tanaman serealia yang menjadi sumber kalori. Hampir sama seperti padi, gandum dipanen dalam bentuk biji, namun tidak bisa dikonsumsi langsung, harus digiling terlebih dahulu. Hasil penggilingan gandum disebut tepung gandum atau yang kita kenal dengan tepung terigu. Biji gandum yang diimpor kemudian digiling oleh industri penepungan di Indonesia yaitu Bogasari, Berdikari, Sriboga dan Panganmas. Hasil penggilingan tepung terigu kemudian dipasarkan ke industri-industri yang menggunakan tepung terigu sebagai bahan bakunya dan juga kepada masyarakat atau rumah tangga

Menurut Ariani (2007), banyaknya impor gandum untuk memenuhi kebutuhan dalam negeri cukup beralasan mengingat bahan pangan ini belum dapat diproduksi di dalam negeri. Gandum dan produk olahannya seperti mi 
mengalami peningkatan konsumsi setiap tahunnya. Dalam kurun waktu sepuluh tahun (1990-1999), laju pertumbuhan jumlah konsumen mi di kota mencapai $56,5 \%$ dan $67 \%$ di desa. Impor gandum Indonesia mencapai 4,3 juta ton pada tahun 2002 dan merupakan importir terbesar ke-enam di dunia pada saat itu dan sekarang Indonesia menempati peringkat ke-empat importir gandum terbesar di dunia.

Adanya permintaan impor gandum di Indonesia ini yang mendorong pentingnya untuk dikaji dan dianalisis faktor-faktor yang mempengaruhi permintaan impor gandum dan trend permintaan impor gandum di Indonesia dari tahun ke tahun. Hal ini dapat dijadikan sebagai referensi tambahan untuk menentukan kebijakan tentang impor gandum di Indonesia.

\section{TINJAUAN PUSTAKA}

\section{Konsumsi Gandum Indonesia}

Pada saat ini diperkirakan konsumsi tepung terigu sekitar $15 \mathrm{~kg} / \mathrm{kapita} / \mathrm{tahun}$ atau sekitar $12 \%$ konsumsi per kapita beras, meningkat dari $13 \mathrm{~kg} / \mathrm{kapita} / \mathrm{tahun}$ pada tahun 1969 yang hanya 5\% dari konsumsi beras per kapita. Tingkat konsumsi tepung gandum (terigu) meningkat sekitar 500\%selama 30 tahun terakhir. Pada saat ini, empat buah pabrik tepung terigu menguasai hampir $90 \%$ pangsa pasar terigu di Indonesia, dan yang terbesar adalah Bogasari yang menguasai sekitar $65 \%$. Industri penggilingan gandum dan pasar tepung terigu di Indonesia lebih mencirikan pasar oligopoli daripada pasar persaingan (Sawit, 2003).

Tingginya tingkat konsumsi mi instan dikarenakan produk turunan yang dihasilkan sangat beragam dan promosinya juga sangat kuat. Banyak ragam jenis, bentuk, rasa dan cara mengolah mi misal mi basah, mi kuah, mi instan dan produk mi lainnya. Produk mi dapat dengan cepat diolah, disajikan dan dikonsumsi dengan kemasan yang bagus dan variasi harga mi sesuai dengan kemampuan konsumen dari golongan atas, menengah maupun bawah. Selain itu mi juga dapat dengan mudah dijumpai di berbagai tempat, tidak hanya di swalayan tetapi juga di pasar tradisional atau warung kecil di pedesaan (Ariani dan Ashari, 2003).

\section{Penelitian Impor Gandum}

Purnomosidi (2004) melakukan penelitian tentang "Permintaan Impor Gandum Indonesia" dengan menggunakan data runtut waktu (time series data). Periode tahun 1972-2002, yang dianalisis dengan regresi Ordinary Least Square (OLS) dan mengunakan pendekatan model koreksi kesalahan (ECM). Variabel yang digunakan meliputi volume permintaan impor gandum sebagai variabel terikat, sedangkan harga gandum internasional, harga beras domestik, pendapatan per kapita dan penggunaan terigu oleh industri makan digunakan sebagai variable bebas.

Dari penelitian tersebut diperoleh hasil bahwa variabel harga gandum internasional signifikan dengan koefisien elastisitas sebesar 0,22 . Jika harga gandum meningkat $1 \%$ maka permintaan impor gandum Indonesia mengalami penurunan sebesar $0,22 \%$ dalam jangka panjang. Variabel harga beras juga signifikan dengan koefisien elastisitas sebesar 0,04. Jika harga beras meningkat $1 \%$ maka permintaan impor gandum akan mengalami kenaikan sebesar $0,04 \%$ dalam jangka panjang. Koefisien jangka panjang variabel pendapatan adalah 1,790535. Tanda koefisien ini positif sesuai dengan teori, dimana pendapatan mempunyai pengaruh positif terhadap permintaan inmpor gandum Indonesia. Variabel penggunaan terigu oleh industri makanan signifikan dengan koefisien elastisitas sebesar $0,2 \%$. Jika penggunaan terigu oleh industri makanan meningkat sebesar $1 \%$ maka permintaan impor gandum Indonesia akan mengalami kenaikan sebesar $0,02 \%$ dalam jangka panjang.

\section{Hipotesis}

1. Diduga pertumbuhan impor gandum Indonesia meningkat.

2. Diduga GNP, jumlah penduduk, harga beras domestik dan penggunaan tepung terigu industri berpengaruh positif terhadap impor gandum Indonesia.

3. Diduga harga gandum internasional dan kurs berpengaruh negatif terhadap impor gandum Indonesia 


\section{METODE PENELITIAN}

Penelitian ini menggunakan metode deskriptif analitis kuantitatif, yaitu mendasarkan pada pemecahan masalah-masalah aktual yang ada sekarang. Data ditunjukkan, disusun, kemudian dijelaskan dan dianalisis sehingga memberikan gambaran mengenai fenomenafenomena yang terjadi, menerangkan hubungan, menguji hipotesis dan membuat prediksi, serta mendapatkan makna dan implikasi dari suatu masalah yang dipecahkan (Nazar, 2005). Menurut Azwar (1998), tujuan penelitian deskriptif adalah untuk membuat pencandraan secara sistematis, faktual dan akurat mengenai fakta-fakta dan sifat-sifat populasi atau daerah tertentu.

\section{Definisi dan Pengukuran Variabel}

1. Volume impor gandum Indonesia adalah besarnya kuantitas gandum yang diimpor oleh Indonesia tiap tahun dan dinyatakan dalam (ton/tahun)

2. Harga gandum internasional adalah harga gandum di pasar internasional (FOB) yang dinilai dengan mata uang (US\$/ton)

3. Harga beras domestik adalah harga beras yang nasional yang berlaku di Indonesia (US\$/ton)

4. Penggunaan tepung terigu industri adalah banyaknya jumlah tepung terigu yang digunakan oleh industri-industri pengolahan tepung terigu yang diukur dalam (ton/tahun)

5. Jumlah penduduk adalah banyaknya penduduk negara Indonesia (jiwa)

6. Kurs atau nilai tukar adalah nilai uang suatu negara terhadap mata uang negara lain. Dalam penelitian ini, nilai tukar yang digunakan adalah nilai tukar rupiah terhadap US \$ 1 per tahun dalam satuan rupiah/US \$

7. GNP (Gross National Product) atau PNB (Produk Nasional Bruto) merupakan nilai produk berupa barang dan jasa yang dihasilkan oleh penduduk suatu negara (nasional) selama satu tahun, termasuk hasil produksi barang dan jasa yang dihasilkan oleh warga negara yang berada di luar negeri, tetapi tidak termasuk hasil produksi perusahaan asing beroperasi di wilayah tersebut (Fischer, 1998)

\section{Analisis Trend Impor Gandum Indonesia}

Untuk mengetahui perkembangan impor gandum di Indonesia menggunakan data time series dalam proyeksi perkembangan permintaan impor gandum yang diperoleh dengan mengestimasi volume impor menggunakan persamaan trend dengan metode least square. Berdasarkan penelitian Sinurat (2007), bentuk persamaan analisis trend permintaan impor gandum adalah sebagai berikut:

$$
\mathrm{Y}=\mathrm{a}+\mathrm{bT}
$$

Keterangan:

Y : Jumlah volume impor gandum Indonesia

a : Konstanta/intersep

$\mathrm{b}$ : Koefisien regresi pengubah waktu/slope

$\mathrm{T}$ : Waktu

\section{Analisis Faktor-Faktor Yang Mempengaruhi Permintaan Impor Gandum Indonesia}

Untuk mengetahui faktor-faktor yang mempengaruhi permintaan impor gandum Indonesia, maka digunakan persamaan regresi linier berganda dimana penaksiran parameternya menggunakan Ordinary Least Square (OLS). Bentuk persamaannya sebagai berikut:

$$
\begin{aligned}
\ln Y= & a+\ln b_{1} X_{1}+\ln b_{2} X_{2}+\ln b_{3} X_{3}+\ln \\
& b_{4} X_{4}+\ln b_{5} X_{5}+\ln b_{6} X_{6}+e
\end{aligned}
$$

Keterangan:

Y : Volume Impor Gandum Indonesia

A : Intersep

$\mathrm{b}_{1}-\mathrm{b}_{6}$ : Koefisien regresi

$\mathrm{X}_{1}$ : Gross National Product (GNP)

$\mathrm{X}_{2}$ : Jumlah Penduduk Indonesia

$\mathrm{X}_{3} \quad$ : Harga Gandum Internasional

$\mathrm{X}_{4}$ : Harga Beras Domestik

$\mathrm{X}_{5} \quad$ : Kurs

$\mathrm{X}_{6}$ : Penggunaan Tepung Terigu Oleh Industri

E : Error

\section{Kesesuaian Model (Goodness of fit)}

Model regresi diatas selanjutnya dilakukan pengujian kesesuaian model, yakni koefisien determinasi $\left(\mathrm{R}^{2}\right.$ ), uji simultan (uji $\mathrm{F}$ ), dan uji parsial (uji t).

\section{a. Koefisien Determinasi $\left(\mathbf{R}^{2}\right)$}

Untuk mengukur kepadatan model, digunakan koefisien determinasi $\left(\mathrm{R}^{2}\right)$ yang 
menunujukkan proporsi dari total variasi variabel bebas yang menjelaskan variabel tak bebas. Rumus menghitung nilai $\mathrm{R}^{2}$ menurut Gujarati (2007) adalah sebagai berikut:

$$
\mathrm{R}^{2}=\frac{E S S}{T S S}
$$

Keterangan:

$\mathrm{R}^{2} \quad$ : Koefisisen determinasi

ESS : Jumlah kuadrat yang diterangkan

TSS : Jumlah kuadrat total

\section{b. Uji Simultan (Uji F)}

Uji $F$ dilakukan untuk menguji secara bersama-sama pengaruh variabel bebas terhadap variabel terikat. Apabila nilai $\mathrm{F}_{\text {hitung }}$ lebih besar dari $\mathrm{F}_{\text {tabel }}$, maka variabelvariabel bebas secara bersama-bersama berpengaruh signifikan terhadap variabel terikat. Menurut Gujarati (2007), nilai $F_{\text {hitung }}$ dapat dirumuskan sebagai berikut:

$$
\begin{aligned}
& \text { Ftabel }=\alpha(\mathrm{k}-1, \mathrm{~N}-\mathrm{k}) \\
& \text { Fhitung }=\frac{R^{2} /(k-1)}{\left(1-R^{2}\right) /(N-k)}
\end{aligned}
$$

Keterangan:

$\mathrm{k}$ : Jumlah parameter yang diestimasi, termasuk konstanta

$\mathrm{N}$ : Jumlah observasi

$\mathrm{R}^{2}$ : Koefisien determinasi

Menentukan hipotesis nol $\left(\mathrm{H}_{0}\right)$ dan hipotesis alternatif $(\mathrm{Ha})$ adalah sebagai berikut:

$\mathrm{H}_{0}: \beta 1=\beta 2=\beta 3=\ldots . .=\beta \mathrm{i}=0$; Artinya semua variabel bebas secara bersamasama tidak berpengaruh terhadap variabel terikat

Ha : $\beta 1 \neq \beta 2 \neq \beta 3 \neq \ldots . . \neq \beta i \neq 0$; Artinya semua variabel bebas secara bersamasama berpengaruh terhadap variabel terikat

Keputusan untuk menolak atau menerima $\mathrm{H}_{0}$ yaitu:

$\mathrm{H}_{0}$ ditolak jika nilai $\mathrm{F}_{\text {hitung }}>\mathrm{F}_{\text {tabel }}$; Artinya semua variabel bebas secara bersamasama berpengaruh terhadap variabel terikat.
$\mathrm{H}_{0}$ diterima jika nilai $\mathrm{F}_{\text {hitung }} \leq$ Ftabel; Artinya semua variabel bebas secara bersama-sama tidak berpengaruh terhadap variabel terikat

\section{c. Uji t (individual test)}

Uji t digunakan untuk mengaetahui tiaptiap variabel bebas terhadap variabel terikat. Nilai $t_{\text {hitung }}$ dapat dirumuskan sebagai berikut:

$$
\begin{aligned}
& \mathrm{t}_{\text {tabel }} \quad=(\alpha / 2, \mathrm{~N}-\mathrm{k}) \\
& \mathrm{t}_{\text {hitung }}=\frac{b_{i}}{S_{e}\left(b_{i}\right)} \\
& \text { dimana } \\
& \text { bi } \quad=\text { koefisien regresi ke- } \mathrm{i} \\
& \mathrm{S}_{\mathrm{e}}\left(\mathrm{b}_{\mathrm{i}}\right)=\text { standard error regresi dari } \mathrm{b}_{\mathrm{i}}
\end{aligned}
$$

Menentukan Hipotesis nol $\left(\mathrm{H}_{0}\right)$ dan Hipotesis alternatif $\left(\mathrm{H}_{\mathrm{a}}\right)$ adalah sebagai berikut:

$\mathrm{H}_{0}: \beta_{\mathrm{i}}=0$; artinya tidak ada pengaruh variabel bebas terhadap variabel terkait $\mathrm{H}_{\mathrm{a}}: \beta_{\mathrm{i}} \neq 0$; artinya ada pengaruh variabel bebas terhadap variabel terkait

Membandingkan nilai thitung untuk masing-masing estimator dengan ttabel dengan kriteria sebagai berikut:

$\mathrm{H}_{0}$ ditolak jika nilai $\mathrm{t}_{\text {hitung }}>\mathrm{t}_{\text {tabel }}$;Artinya variabel bebas ke-i signifikan, yang secara parsial berpengaruh terhadap variabel terikat

$\mathrm{H}_{0}$ diterima jika nilai $\mathrm{t}_{\text {hitung }} \leq \mathrm{t}_{\text {tabel }}$;Artinya variabel bebas ke-i tidak signifikan, yang secara parsial tidak berpengaruh terhadap variabel terikat

\section{HASIL ANALISIS DAN PEMBAHASAN Analisis Trend Pertumbuhan Impor Gandum Indonesia}

Analisis trend merupakan suatu metode analisis yang ditujukan untuk melakukan suatu estimasi atau peramalan pada masa yang akan datang. Perhitungan trend dilakukan pada data volume impor gandum Indonesia dengan kurun waktu selama 20 tahun dari 1992-2011. Analisis trend yang dilakukan akan memproyeksikan volume permintaan impor gandum oleh Indonesia dalam sepuluh tahun ke depan. 


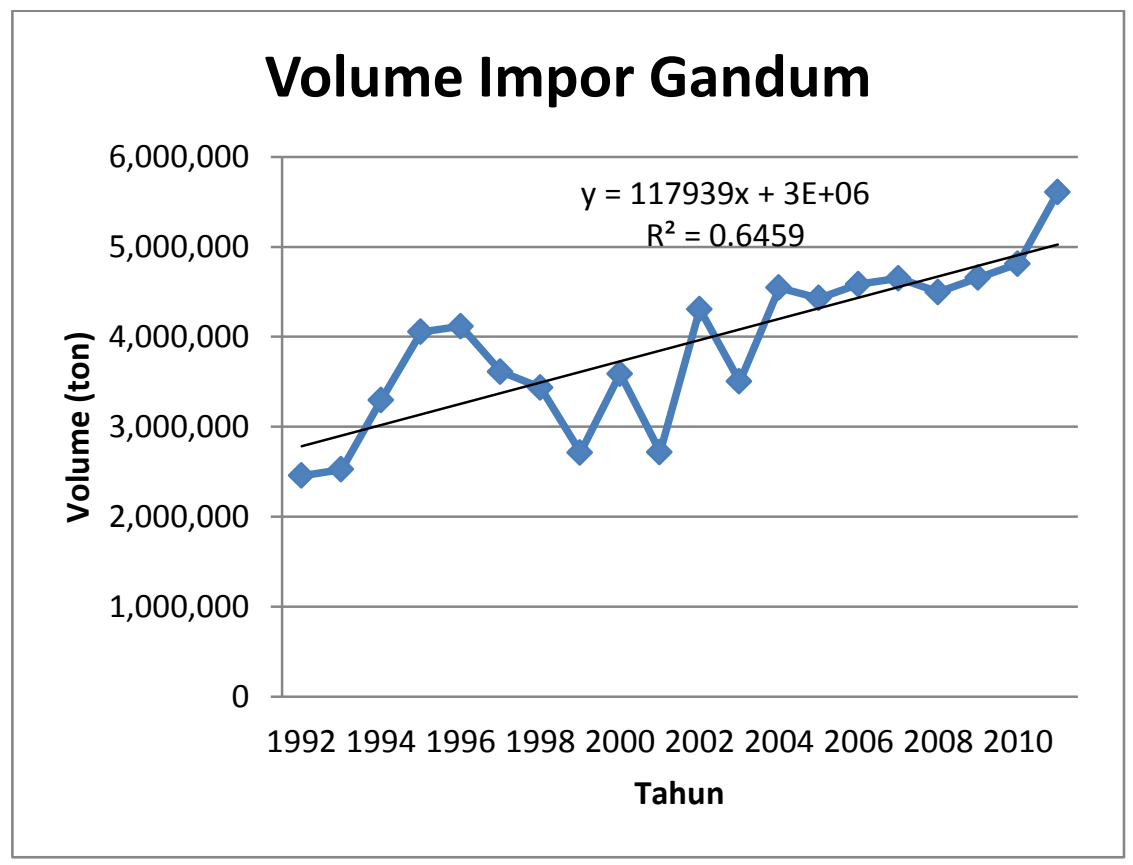

Dari hasil analisis trend volume impor gandum Indonesia, diperoleh persamaan trend sebagai berikut:

$$
Y=11.793 x+3 E+06
$$

Persamaan trend di atas mempunyai slope positif yang menunjukan kecenderungan volume impor gandum Indonesia mengalami peningkatan setiap tahunnya. Pada persamaan trend tersebut, diperoleh nilai slope sebesar 11.793 yang berarti rata-rata permintaan impor gandum Indonesia setiap tahunnya mengalami peningkatan sebesar 11.793 ton.

Impor gandum Indonesia dari tahun 1992 masyarakat berpendapatan besar. Peralihan pola konsumsi masyarakat yang menginginkan makanan praktis menjadikan gandum sebagai pilihan utama, karena produk olahan gandum dapat disajikan dan dikonsumsi secara praktis dan cepat saji seperti mi, roti dan biskuit, sehingga gandum menjadi komoditas yang sangat vital di Indonesia. Untuk memenuhi kebutuhan gandum tersebut, maka tidak ada

cara lain selain harus melakukan impor karena Indonesia bukan negara pengahsil gandum. Hal ini yang menyebabkan impor gandum Indonesia terus mengalami peningkatan.

Tabel 1. Uji t Trend Impor Gandum Indonesia

\begin{tabular}{|c|r|r|r|r|}
\hline \multirow{2}{*}{ Model } & \multicolumn{2}{|c|}{ Unstandardized Coefficients } & \multirow{2}{*}{T $_{\text {hitung }}$} & \multirow{2}{*}{ Signifikansi } \\
\cline { 2 - 3 } & \multicolumn{1}{|c|}{ B } & Std. Error & & 0.000 \\
\hline (Constant) & $-2.32 \mathrm{E}+08$ & 41200370.86 & -5.634637 & 0.000 \\
\hline Waktu & 117938.6 & 20584.66144 & 5.729441 & \\
\hline
\end{tabular}

sampai tahun 2011 cenderung meningkat walaupun beberapa kali mengalami fluktuasi terutama pada tahun 1998 dan 1999 karena pada saat itu Indonesia tengah dilanda krisis moneter. Komoditas gandum adalah jenis serealia yang mempunyai sifat unggul dibandingkan dengan komoditas sumber kalori lainnya seperti jagung dari segi modernitas pangan. Kebutuhan gandum semakin meningkat karena produk gandum yang dapat dinikmati oleh semua kalangan masyarakat baik yang mempunyai pendapatan kecil maupun

\section{Analisis Regresi Linear Berganda}

Pengujian regresi linear berganda dilakukan untuk mengetahui apakah semua variabel independen memiliki pengaruh secara bersama-sama terhadap variabel dependen. Untuk mengetahui secara serentak pengaruh dari variabel- variabel bebas terhadap volume impor gandum di Indonesia digunakan uji F. Hasil analisis regresi impor gandum di Indonesia diperoleh $\mathrm{F}$ hitung sebesar 18,495 dengan tingkat 
Tabel 2. Analisis Linear Berganda

\begin{tabular}{|l|r|r|r|r|}
\hline \multicolumn{1}{|c|}{ Variabel } & \multicolumn{1}{c|}{$\begin{array}{c}\text { Koefisien } \\
\text { Regresi }\end{array}$} & \multicolumn{1}{c|}{ Std. Error } & \multicolumn{1}{c|}{ Thitung } & \multicolumn{1}{c|}{ Signifikansi } \\
\hline Konstanta & $-24.812^{* *}$ & 8.390 & -2.957 & 0.011 \\
\hline GNP & $0.253^{*}$ & 0.127 & 1.997 & 0.067 \\
\hline Jumlah Penduduk & $3.025^{* * *}$ & 0.759 & 3.985 & 0.002 \\
\hline $\begin{array}{l}\text { Harga Gandum } \\
\text { Internasional }\end{array}$ & $0.491^{*}$ & 0.274 & 1.790 & 0.097 \\
\hline $\begin{array}{l}\text { Harga Beras } \\
\text { Domestik }\end{array}$ & $0.201 \mathrm{~ns}$ & 0.126 & 1.595 & 0.135 \\
\hline Kurs & $-0.528^{* *}$ & 0.190 & -2.773 & 0.850 \\
\hline $\begin{array}{l}\text { Penggunaan Tepung } \\
\text { Terigu }\end{array}$ & $0.009 \mathrm{~ns}$ & 0.048 & 0.193 & \\
\hline Adj $R$ squared & 0.847 & & & \\
\hline Fhitung & 18.495 & & \\
\hline$*$ & Signifikan pada taraf $10 \%$ & & \\
\hline$* * \quad$ Signifikan pada taraf 5\% & & \\
\hline$* * * \quad$ Signifikan pada taraf $1 \%$ & & \\
\hline ns Non signifikan &
\end{tabular}

signifikasi 0,000 . Oleh karena probabilitas 0,000 jauh lebih kecil dari 0,05 , maka dapat disimpulkan bahwa secara serentak variabel GNP, jumlah penduduk, harga gandum internasional, harga beras domestik, kurs dan penggunaan tepung terigu oleh industri berpengaruh secara bersama-sama terhadap volume permintaan impor gandum di Indonesia. Dikatakan model regresi dapat digunakan untuk memprediksi volume impor gandum.

Koefisien determinasi $\left(R^{2}\right)$ merupakan salah satu nilai statistik yang mampu memberikan informasi mengenai variasi variabel dependen yang dapat dijelaskan oleh model regresi yang digunakan. Akan tetapi dalam analisis regresi linear berganda koefisien determinasi yang digunakan adalah berupa adjusted $R^{2}$. Kelemahan mendasar penggunaan $R^{2}$ adalah bias terhadap jumlah variabel independen yang dimasukkan ke dalam model. Setiap penambahan satu variabel independen, maka $R^{2}$ pasti meningkat tidak peduli apakah variabel independen tersebut berpengaruh secara signifikan terhadap variabel dependen. Oleh karena itu, pada saat mengevaluasi goodness fit model regresi berganda digunakan adjusted $R^{2}$.

Nilai adjusted $R^{2}$ dari hasil analisis regresi sebesar 0,847 yang berarti bahwa sekitar $84,7 \%$ dari variasi atau perubahan volume impor gandum di Indonesia dapat dijelaskan oleh parameter variabel GNP, jumlah penduduk, harga gandum internasional, harga beras domestik, kurs dan penggunaan tepung terigu oleh industri. Sedangkan $15,3 \%$ sisanya dapat dijelaskan oleh variasi atau perubahan variabel lain di luar model.

\section{Uji t (individual test)}

Masing-masing variabel yang digunakan dalam penelitian ini akan dijelaskan sebagai berikut:

\section{GNP}

Variabel pendapatan nasional menggunakan nilai Gross National Product $(G N P)$ per kapita menurut harga konstan tahun 2005. GNP berpengaruh nyata terhadap volume impor gandum pada taraf $10 \%$ (Sig. 0,067). Koefisien regresi GNP bernilai 0,253 yang berarti jika pendapatan nasional (GNP) mengalami kenaikan sebesar $1 \%$, maka volume impor gandum akan naik sebesar $0,253 \%$ dengan asumsi variabel independen lainnya tetap. Variabel GNP inelastis terhadap volume impor, karena setiap kenaikan GNP sebesar 1\% diikuti dengan kenaikan volume impor dengan persentase lebih kecil yaitu sebesar $0,253 \%$. Dengan demikian, variabel GNP berpengaruh positif terhadap volume impor gandum Indonesia, sehingga semakin tinggi GNP, maka 
permintaan volume impor pun juga akan meningkat. Menurut Goodwin dan Drummond (1982), faktor pendapatan mempengaruhi permintaan suatu barang karena pendapatan menunjukan kemampuan konsumen untuk memperoleh barang yang menjadi kebutuhannya. GNP Indonesia dari ke tahun ke tahun mengalami peningkatan. Sejalan dengan meningkatnya GNP, daya beli masayarakatpun semakin meningkat, tanpa kecuali untuk kebutuhan konsumsi. Produk olahan gandum dapat menjangkau semua lapisan masyarakat, mulai dari masyarakat kelas bawah dengan pendapatan kecil, mereka dapat membeli mi instan yang harganya terjangkau, sementara masyarakat kelas menengah atas dapat menikmati berbagai jenis roti. Dengan adanya peningkatan pendapatan masyarakat, maka permintaan volume impor gandum akan meningkat, karena masyarakat mempunyai daya beli lebih untuk produk gandum.

\section{Jumlah Penduduk}

Variabel jumlah penduduk berpengaruh nyata pada impor gandum Indonesia pada taraf $1 \%$ (Sig. 0,002). Koefisien regresi variabel jumlah penduduk bernilai 3,025 yang berarti jika jumlah penduduk mengalami kenaikan sebesar $1 \%$, maka volume impor gandum akan naik sebesar 3,025\% dengan asumsi variabel independen lainnya tetap. Variabel jumlah penduduk bersifat elastis terhadap volume impor, karena setiap kenaikan jumlah penduduk sebesar $1 \%$ diikuti dengan kenaikan volume impor dengan persentase lebih besar yaitu sebesar $3,025 \%$. Dengan demikian, variabel jumlah penduduk berpengaruh positif terhadap volume impor gandum di Indonesia, sehingga jika jumlah penduduk meningkat, maka volume impor gandum juga akan meningkat. Hasil analisis ini tentunya cukup beralasan karena semakin meningkat jumlah penduduk maka kebutuhan bahan makanan tidak terkecuali gandum akan semakin meningkat. Dalam dua puluh tahun terakhir, jumlah penduduk Indonesia mengalami peningkatan lebih dari $20 \%$. Jumlah penduduk dalam penelitian ini digunakan untuk indikator ukuran konsumsi. Meningkatnya jumlah penduduk menggeser kurva permintaan impor gandum ke kanan yang artinya impor mengalami peningkatan. Saat ini, konsumsi gandum nasional yaitu $21 \mathrm{~kg} / \mathrm{kapita} / \mathrm{tahun}$ dengan jumlah penduduk Indonesia yaitu sekitar 250 juta jiwa. Jumlah konsumsi gandum tersebut mempunyai andil 12\% dalam konsumsi total pangan nasional, sehingga jika jumlah penduk naik terus menerus, maka konsumsi pangan dipastikan akan naik tidak terkecuali pangan gandum yang berdampak semakin membengkaknya volume impor gandum Indonesia.

\section{Harga Gandum Internasional}

Variabel harga gandum internasional berpengaruh nyata pada impor gandum Indonesia pada taraf 10\% (Sig. 0,097). Koefisien regresi harga gandum internasional bernilai 0,491 yang berarti jika harga gandum internasional mengalami kenaikan sebesar $1 \%$, maka volume impor gandum akan naik sebesar $0,491 \%$ dengan asumsi variabel independen lainnya tetap. Harga gandum internasional bersifat inelastis terhadap volume impor, karena setiap kenaikan harga gandum internasional sebesar $1 \%$ diikuti dengan kenaikan volume impor dengan persentase lebih kecil yaitu sebesar 0,491\%. Dengan demikian, variabel harga gandum internasional berpengaruh positif terhadap impor gandum Indonesia, sehingga jika harga gandum internasional naik, volume impor gandum juga akan mengalami kenaikan. Hasil analisis ini tidak sesuai dengan hipotesis dan teori yang menyatakan bahwa kenaikan harga gandum internasional akan menurunkan volume impor gandum Indonesia. Harga gandum dunia mengalami kecenderungan naik setiap tahunnya yang disebabkan negaranegara produsen gandum banyak terganggu akibat cuaca yang buruk seperti contoh Australia yang mengalami penurunan produksi karena curah hujan yang sangat tinggi dan Amerika Serikat yang mengalami kekeringan. Saat ini, dengan harga gandum dunia yang saat ini hampir mencapai US $\$ 400$ per ton, permintaan impor gandum tetap tinggi dan cenderung meningkat setiap tahunnya, karena Indonesia tidak dapat memproduksi gandum sendiri untuk memenuhi kebutuhan dalam negeri. Pajak impor yang sangat kecil yaitu hanya sebesar 5\% semakin menguntungkan para pelaku impor, karena 
walaupun harga gandum dunia naik, para importir diuntungkan dengan biaya impor yang ringan. Pemerintah dalam hal ini kurang melakukan pengawasan terhadap pelaku impor sehingga mereka dapat dengan bebas melakukan impor gandum tanpa adanya pengawasan yang ketat dari pemerintah

\section{Harga Beras Domestik}

Beras pada penelitian ini adalah sebagai barang substitusi dari gandum. Variabel harga beras domestik memiliki Thitung sebesar 1,595 (Sig. 0,135) sehingga tidak berpengaruh signifikan terhadap volume impor gandum Indonesia. Beras dalam penelitian ini digunakan sebagai komoditas substitusi gandum dimana dalam teori disebutkan bahwa barang tertentu akan saling mensubstitusi dengan barang lain. Dalam 20 tahun terakhir, harga beras domestik mengalami fluktuasi harga, namun kondisi tersebut tidak berpengaruh terhadap volume impor gandum Indonesia, karena beras dan gandum merupakan komoditi yang memiliki nilai kebutuhan masing-masing di masyarakat. Selain itu, konsumsi produk olahan gandum memang sudah lama populer di Indonesia. Walaupun beras sudah menjadi makanan pokok masyarakat Indonesia, pada kenyataannya masyarakat telah mengalami perubahan pola konsumsi ke makanan berbahan dasar gandum, sehingga makanan berbahan dasar gandum sudah mempunyai tempat sendiri dalam pola konsumsi masyarakat.

\section{Kurs}

Dollar Amerika merupakan mata uang yang digunakan dalam perdagangan internasional. Kurs berpengaruh signifikan terhadap volume impor gandum Indonesia pada taraf 5\% (Sig. 0,016). Nilai koefisien regresi kurs sebesar $-0,528$ yang berarti jika nilai tukar rupiah mengalami penurunan (rupiah menguat) sebesar $1 \%$, maka volume impor gandum akan naik sebesar $0.528 \%$ dengan asumsi variabel independen lainnya tetap. Dengan demikian, variabel kurs berpengaruh negatif terhadap volume impor gandum Indonesia, sehingga jika rupiah menurun (nilai tukar rupiah terhadap dollar meningkat), maka akan meningkatkan volume impor gandum Indonesia. Hal ini sesuai dengan hipotesis penelitian, karena jika nilai tukar rupiah meningkat artinya nilai dollar sebagai mata uang perdagangan internasional melemah, sehingga Indonesia mempunyai nilai uang yang lebih untuk mengimpor gandum. Jika dilihat pada kenyataan yang ada, kurs atau nilai tukar rupiah terhadap dollar semakin melemah, namun impor gandum justru semakin meningkat yang dikarenakan masyarakat Indonesia tidak dapat terlepas dari pola konsumsi yang beralih ke makanan berbasis gandum. Perubahan pola konsumsi tersebut semakin meningkatkan impor gandum walaupun kondisi rupiah terus melemah, nyatanya kebutuhan gandum dalam negeri harus tetap dipenuhi.

\section{Penggunaan Tepung Terigu oleh Industri}

Populernya produk gandum di Indonesia menyebabkan semakin banyaknya industri yang menggunakan tepung terigu sebagai bahan bakunya karena banyak sekali produk turunan yang dapat dihasilkan dari komoditas ini. Penggunaan tepung terigu oleh industri mempunyai nilai signifikansi 0,850 yang berarti tidak berpengaruh signifikan terhadap volume impor gandum di Indonesia, sehingga fluktuasi penggunaan tepung terigu oleh industri tidak akan mempengaruhi volume impor gandum Indonesia. Penggunaan tepung terigu oleh industri bersifat sangat fluktuaktif karena harga tepung terigu dalam negeri juga berfluktuasi dari tahun ke tahun. Sementara penggunaan tepung terigu dalam negeri mengalami fluktuasi, jumlah impor gandum tetap meningkat, karena impor gandum Indonesia dikuasai oleh beberapa industri penggilingan besar seperti PT. Bogasari yang mengimpor sekitar 300 ribu ton/bulan, sementara tepung terigu banyak digunakan oleh beberapa industri pengolahan makanan. Fluktuasi jumlah tepung terigu yang digunakan oleh industri pengolahan terigu tidak berakibat pada volume gandum yang diimpor oleh importir seperti PT. Bogasari tersebut, karena mereka akan tetap melakukan impor gandum untuk memenuhi stok terigu dan untuk mempermudah akses konsumsinya.

Gandum merupakan komoditas strategis yang dapat menjadi bahan pangan alternatif bagi beras. Gandum memiliki kandungan karbohidrat 
yang tidak jauh berbeda jika dibanding dengan komoditas serealia lain seperti sorgum, jagung dan beras sedangkan kandungan proteinnya lebih tinggi dari sorgum, jagung dan beras. Bahan pangan dari gandum yang dikenal dengan tepung terigu sudah menjadi sumber bahan pangan alternatif yang merata bagi penduduk Indonesia dari kota sampai ke pelosok desa. Konsumsi gandum di Indonesia dari tahun ke tahun semakin meningkat disebabkan oleh adanya pertambahan jumlah penduduk dan perubahan pola makan masyarakat yang telah bergeser ke makanan yang berbasis tepung terigu seperti mi instan dan roti.

Meskipun gandum dapat menjadi bahan pangan alternatif namun ketersediaannya yang tidak mencukupi justru malah menjadi permasalahan. Hingga saat ini, untuk memenuhi kebutuhan gandum dalam negeri Indonesia mengimpor gandum dari negara lain. Tingginya permintaan gandum dunia ini menunjukkan besarnya konsumsi gandum sebagai bahan pangan karbohidrat non beras. Gandum mempunyai keunggulan yaitu mengandung protein yang mempunyai sifat khas gluten yang tidak dimiliki tanaman serealia lain seperti padi dan jagung, disamping itu tanaman gandum bisa dikembangkan menjadi tepung sementara padi dan jagung dimakan sebagai biji dan kurang dikembangkan, kebutuhan gandum terus meningkat terutama untuk diversifikasi pangan.

Sebagian besar penduduk Indonesia lebih banyak menggunakan pengeluarannya untuk makanan. Untuk penduduk miskin, persentase pengeluaran rumah tangga yang digunakan untuk makanan jauh lebih besar yaitu sekitar $70 \%$ dari total pengeluaran. Bergeser menu makanan pada kelompok berpendapatan menengah dan rendah, berlalih begitu cepat ke makanan yang berasal dari tepung terigu. Pola yang lazim yang terjadi di belahan negara Asia lainnya adalah pergeseran konsumsi ke tepung terigu pada kelompok berpendapatan menengah dan rendah terjadi sangat lambat. Di Indonesia, laju peningkatan konsumsi tepung terigu hampir sama antar berbagai kelompok pendapatan, walau tingkat konsumsi perkapita kelompok berpendapatan tinggi lebih besar. Menurut Sawit
(2003), pada tahun 2003 konsumsi tepung terigu hanya $15 \mathrm{~kg} / \mathrm{kapita} /$ tahun, namun belakangan ini meningkat hingga $21 \mathrm{~kg} / \mathrm{kapita} / \mathrm{tahun}$. Hal ini mengindikasikan bahwa gandum dapat dinikmati oleh semua kalangan dengan produk olahan yang mempunyai banyak variasi harga.

Harga gandum dunia sering tidak stabil yang dipengaruhi oleh jumlah produksi gandum yang beredar di pasar internasional. Pada saat produksi gandum sejumlah negara mengalami peningkatan, maka harga akan turun. Sedangkan jika jumlah produksi sudah stabil atau turun maka harga gandum dunia akan meningkat kembali. Selain dipengaruhi oleh jumlah produksi dunia, kenaikan harga gandum dunia juga disebabkan oleh naiknya konsumsi global terhadap gandum yang melebihi kapasitas produksi. Penurunan produksi gandum dunia disebabkan oleh adanya kegagalan panen sejumlah negara penghasil gandum di dunia. Pada tahun 2011, harga gandum dunia mencapai lebih dari US\$300/ton, namun permintaan impor gandum Indonesia tetap tinggi. Pemerintah menerapkan pajak impor gandum hanya 5\% yang sangat menguntungkan bagi importir, selain itu pemerintah minim dalam melakukan pengawasan terhadap pelaku impor gandum, sehingga pengadaan gandum dapat dilakukan secara liberal.

Indonesia merupakan negara importir gandum terbesar keempat di dunia. Kebutuhan gandum domestik setiap tahun meningkat disebabkan oleh semakin berkembangnya makanan berbasis tepung terigu. Menurut data FAO, perkembangan impor gandum Indonesia dari tahun 1992-2011 setiap tahunnya rata-rata meningkat sekitar 6,4\%. Dengan kondisi perekonomian saat ini dan nilai tukar rupiah yang rendah, tentu sangat memberatkan untuk melakukan impor, namun bagaimanapun juga kebutuhan gandum nasional harus tetap dipenuhi dengan impor.

Pada saat ini, industri penggilingan biji gandum atau industri penepungan menjadi industri yang memiliki prospek baik, mengingat semakin banyaknya industri atau usaha kecil menengah yang membuat makanan dengan bahan dasar tepung terigu. Menurut APTINDO (2007), penggunaan tepung terigu oleh industri 
terbesar adalah oleh industri tradisional (UKM dan industri rumah tangga) sebesar 63,6\%, kemudian oleh industri besar modern sebesar $31,8 \%$ dan untuk rumah tangga sebesar $4,6 \%$. PT Bogasari sebagai industri penggilingan biji gandum terbesar di Indonesia memiliki kelebihan dibandingkan dengan industri penggilingan lain yaitu memiliki modal yang besar, kualitas produksi yang unggul dan promosi yang kuat. Dengan kelebihan tersebut, Bogasari mempunyai pangsa pasar yang sangat dominan, sehingga jika tepung terigu yang digunakan oleh industri-industri kecil mengalami fluktuasi, tidak akan berpengaruh terhadap pengadaan gandum yang dilakukan Bogasari. Hal tersebut disebabkan karena sebagai importir gandum terbesar, Bogasari akan tetap melakukan impor gandum dengan tujuan untuk memenuhi stok dan memudahkan akses konsumsi

\section{KESIMPULAN}

1. Volume impor gandum Indonesia mengalami peningkatan dari tahun ke tahun. Dari perhitungan trend diperoleh hasil bahwa setiap tahun akan terjadi penambahan volume impor sekitar 11.793 ton

2. GNP, jumlah penduduk dan harga gandum internasional berpengaruh signifikan terhadap volume impor gandum dengan hubungan positif

3. Kurs berpengaruh signifikan terhadap volume impor gandum dengan hubungan negatif

\section{DAFTAR PUSTAKA}

Ariani, M dan Ashari. 2003. Arah, Kendala dan Pentingnya Diversifikasi Konsumsi Pangan di Indonesia. Forum Agro Ekonomi. Vol. 21, No. 2. Desember. Bogor.

Azwar, S. 1998. Metodologi Penelitian. Pustaka Belajar. Yogyakarta.

Gujarati, D. 1999. Ekonometrika Dasar Edisi I. Terjemahan: Sumarno Zain. Erlangga. Jakarta.

Nazar, M. 2005. Metode Penelitian Ghalia Indonesia. Jakarta.
Purnomosidi, B. A. 2004. Permintaan Impor Gandum Indonesia. Fakultas Ekonomi Universitas Gadjah Mada. Yogyakarta.

Sawit, M. H. 2003. Kebijakan Gandum: Terigu Harus Mampu Menumbuhkembangkan Industri Pangan Dalam Negeri. <http://pse.litbang.deptan.go.id/publikasi/ AKP 12 2003 >. Diakses pada tanggal 16 November 2013. 